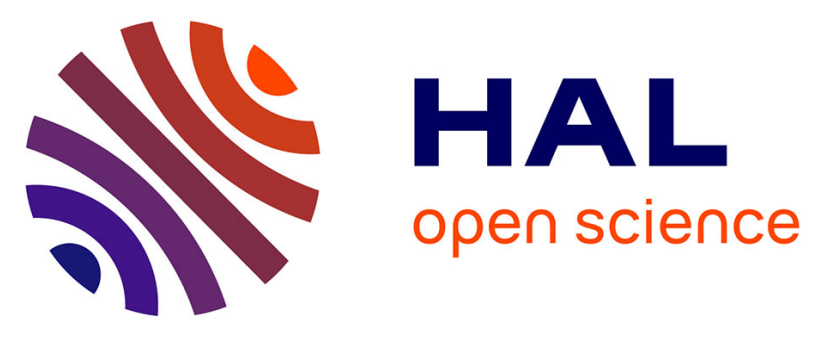

\title{
Carbon nanotube/alumina and graphite/alumina composite coatings on stainless steel for tribological applications
}

Karim Hentour, Alexis Marsal, Viviane Turq, Alicia Weibel, Florence Ansart, Jean-Michel Sobrino, Yan Ming Chen, Julien Garcia, Pierre-François Cardey, Christophe Laurent

\section{To cite this version:}

Karim Hentour, Alexis Marsal, Viviane Turq, Alicia Weibel, Florence Ansart, et al.. Carbon nanotube/alumina and graphite/alumina composite coatings on stainless steel for tribological applications. Materials Today, 2016, vol. 8, pp. 118-126. 10.1016/j.mtcomm.2016.07.007 . hal-01486934

\section{HAL Id: hal-01486934 https://hal.science/hal-01486934}

Submitted on 10 Mar 2017

HAL is a multi-disciplinary open access archive for the deposit and dissemination of scientific research documents, whether they are published or not. The documents may come from teaching and research institutions in France or abroad, or from public or private research centers.
L'archive ouverte pluridisciplinaire HAL, est destinée au dépôt et à la diffusion de documents scientifiques de niveau recherche, publiés ou non, émanant des établissements d'enseignement et de recherche français ou étrangers, des laboratoires publics ou privés. 


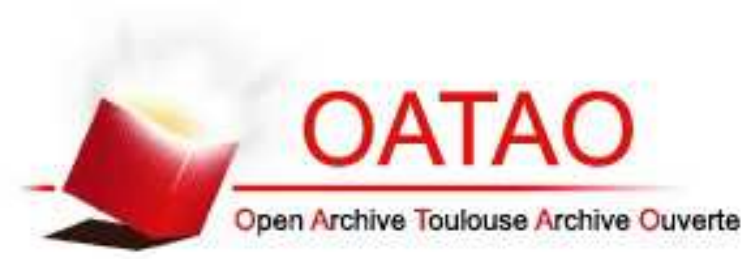

\section{Open Archive TOULOUSE Archive Ouverte (OATAO)}

OATAO is an open access repository that collects the work of Toulouse researchers and makes it freely available over the web where possible.

This is an author-deposited version published in : http://oatao.univ-toulouse.fr/ Eprints ID : 16746

To link to this article : DOI:10.1016/j.mtcomm.2016.07.007

URL : http://dx.doi.org/10.1016/j.mtcomm.2016.07.007

To cite this version : Hentour, Karim and Marsal, Alexis and Turq, Viviane and Weibel, Alicia and Ansart, Florence and Sobrino, JeanMichel and Chen, Yan Ming and Garcia, Julien and Cardey, PierreFrançois and Laurent, Christophe Carbon nanotube/alumina and graphitelalumina composite coatings on stainless steel for tribological applications. (2016) Materials Today, vol. 8. pp. 118126. ISSN 1369-7021

Any correspondence concerning this service should be sent to the repository administrator: staff-oatao@ listes-diff.inp-toulouse.fr 


\title{
Carbon nanotube/alumina and graphite/alumina composite coatings on stainless steel for tribological applications
}

\author{
Karim Hentour ${ }^{\mathrm{a}, \mathrm{b}}$, Alexis Marsal ${ }^{\mathrm{a}, \mathrm{b}}$, Viviane Turq ${ }^{\mathrm{a}}$, Alicia Weibel ${ }^{\mathrm{a}}$, Florence Ansart ${ }^{\mathrm{a}}$, \\ Jean-Michel Sobrino $^{\mathrm{b}}$, Yan Ming Chen ${ }^{\mathrm{b}}$, Julien Garcia ${ }^{\mathrm{b}}$, Pierre-François Cardey ${ }^{\mathrm{c}}$, \\ Christophe Laurent ${ }^{\mathrm{a}, *}$ \\ a CIRIMAT, Université de Toulouse, CNRS, INPT, UPS, 118, Route de Narbonne, 31062, Toulouse Cedex 9, France \\ b CETIM (Centre Technique des Industries Mécaniques), 52, Avenue Félix Louat, CS 80067, 60304, Senlis Cedex, France \\ ' CETIM (Centre Technique des Industries Mécaniques), 7, Rue de la Presse, CS 50802, 42952, Saint-Étienne Cedex 1, France
}

Keywords:

Carbon nanotubes

Graphite

Alumina

Sol gel coatings

Friction

Wear

\begin{abstract}
A B S T R A C T
Carbon/alumina coatings on stainless steel are prepared by a sol-gel route, using either carbon nanotubes (8 walls on average) or graphite flakes. The friction coefficient against a steel ball is decreased by a factor of $4-5$ compared to pure alumina and wear is reduced by a factor of 2 with graphite flakes. A Raman spectroscopy study of selected specimens outside and inside the worn surface shows that the carbon nanotubes are not dramatically damaged whereas the graphite flakes are broken into graphene layers. The reasons why graphite is more effective than the carbon nanotubes, for the same carbon content, to improve the tribological behavior are discussed.
\end{abstract}

\section{Introduction}

Austenitic stainless steels are widely used in the aerospace, energy, medical and food industries because of their resistance to corrosion but they are highly susceptible to adhesive wear (seizure), therefore leading to a significant loss of profitability and possibly to some environmental impact. Carbon-containing composites are of particular interest as self-lubricating materials showing a high resistance to friction and wear, preventing the need for liquid lubricants. Reports on the tribological behavior of metal[1-11] and ceramic-matrix [12-17] bulk composites containing carbon nanotubes (CNTs) are increasingly abundant. However, the comparison of the results reported by different groups is hampered notably because different CNTs are used, the preparation routes markedly differ and the tribological testing conditions (counterface, load, sliding distance, relative humidity, temperature) vary widely. Moreover, it is either undesirable or impossible to use bulk composites for applications such as the protection of austenitic steels. Therefore, composite coatings are to be preferred, such as CNT-metal electroless coatings [3] and plasma-sprayed CNT/ $\mathrm{Al}_{2} \mathrm{O}_{3}$ coatings [18,19]. Balani et al. [18] reported that the sliding wear

\footnotetext{
* Corresponding author.

E-mail address: laurent@chimie.ups-tlse.fr (C. Laurent).
}

volume loss of a $8 \mathrm{wt} . \% \mathrm{CNT} / \mathrm{Al}_{2} \mathrm{O}_{3}$ coating against a $\mathrm{ZrO}_{2}$ pin (dry conditions, normal load $48 \mathrm{~N}$ ) was 49 times lower than for an $\mathrm{Al}_{2} \mathrm{O}_{3}$ coating. Keshri et al. [19] reported a $72 \%$ increase in wear resistance against a WC ball ( $298 \mathrm{~K}$, ball-on-disk tribometer) for a 8 wt.\% $\mathrm{CNT} / \mathrm{Al}_{2} \mathrm{O}_{3}$ coating compared to $\mathrm{Al}_{2} \mathrm{O}_{3}$. Note that these results are partly attributed to indirect effects of the presence of CNTs, such as a locally enhanced densification of the wear surface and a higher toughness of the coating through CNTs bridging between the splats and/or $\mathrm{Al}_{2} \mathrm{O}_{3}$ grains. Graphite $/ \mathrm{Al}_{2} \mathrm{O}_{3}$ bulk composites were shown [20] to have a friction coefficient half of that of pure $\mathrm{Al}_{2} \mathrm{O}_{3}$. A low shear strength in the sliding direction and high compression strength in the direction of the load (i.e. perpendicular to the sliding direction) are beneficial to lower the friction coefficient. Laminated graphite $/ \mathrm{Al}_{2} \mathrm{O}_{3}$ composites were reported [21] to show significantly better friction and wear behaviors than monolithic graphite $/ \mathrm{Al}_{2} \mathrm{O}_{3}$ composites (against an $\mathrm{Al}_{2} \mathrm{O}_{3}$ ball, dry conditions room temperature) because graphite particles can be easily dragged on to the friction surface from the graphite layers. Changes in the layer spacing and in the graphite volume fraction affect the formation of lubricating and transferring films, loadbearing capacities and wear mechanisms of the materials. The aims of the present work are to shape $\mathrm{CNT} / \mathrm{Al}_{2} \mathrm{O}_{3}$ coatings onto an austenitic 304-L stainless steel substrate, to compare their tribological behavior to that of pure $\mathrm{Al}_{2} \mathrm{O}_{3}$ and graphite $/ \mathrm{Al}_{2} \mathrm{O}_{3}$ coatings 


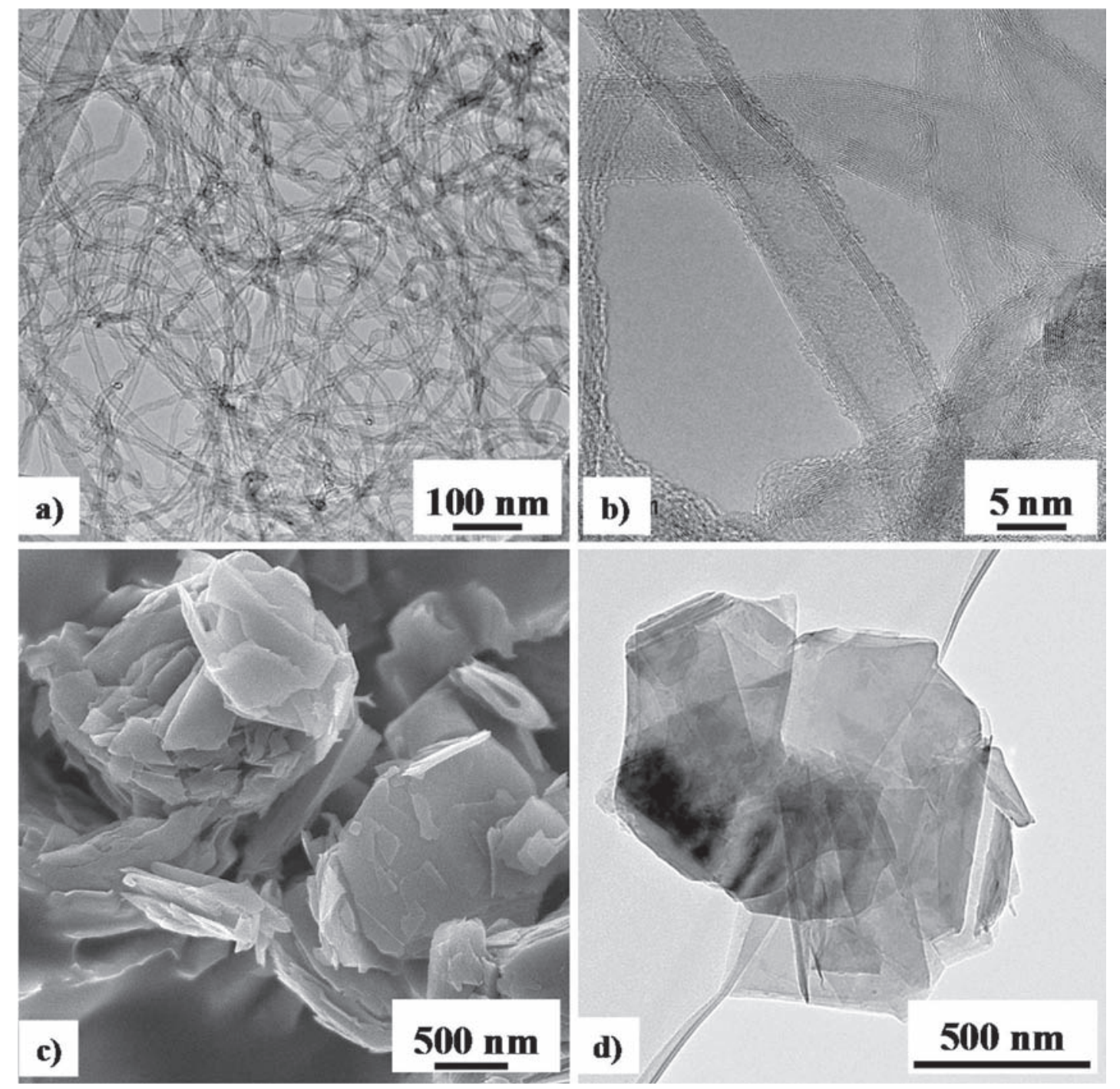

Fig. 1. TEM images of the CNTs (a and b) and FESEM image (c) and TEM image (d) of graphite flakes.

and to explain why graphite is more effective than CNTs to improve the tribological behavior.

\section{Experimental methods}

\subsection{Raw materials}

A CNT sample described in detail elsewhere [10] was purchased from Nanocyl (Belgium). TEM images (Fig. $1 \mathrm{a}$ and b) show that the CNTs are mostly not bundled and contain a fair number of defects along their lengths. CNTs with 3-22 walls are observed. CNTs with 8 walls are dominant (30\%) with CNTs with 7 and 9 walls (both 16\%) the second most abundant populations.

The average number of walls is equal to 8.5 (rounded to 8). The average CNT outer diameter is $10.2 \mathrm{~nm}$ and length is below $1.5 \mu \mathrm{m}$. The specific surface area of the sample is $242 \mathrm{~m}^{2} \mathrm{~g}^{-1}$, in agreement with calculations from geometrical data [22]. The CNTs were carboxyl-functionalized with a nitric acid solution $\left(3 \mathrm{~mol} \mathrm{~L}^{-1}\right)$ as described elsewhere [23]. Graphite platelets (Fig. 1c and d) were purchased from Abcr (Germany). Flakes about $15 \mathrm{~nm}$ thick are agglomerated into platelets about $1.5 \mu \mathrm{m}$ in size. The specific surface area of the sample is $20 \mathrm{~m}^{2} \mathrm{~g}^{-1}$.

An aqueous aluminum chloride hexahydrate $\left(\mathrm{AlCl}_{3} \cdot 6 \mathrm{H}_{2} \mathrm{O}\right)$ solution $\left(0.13 \mathrm{~mol} \mathrm{~L}^{-1}\right)$ was poured into an excess of ammonia solution

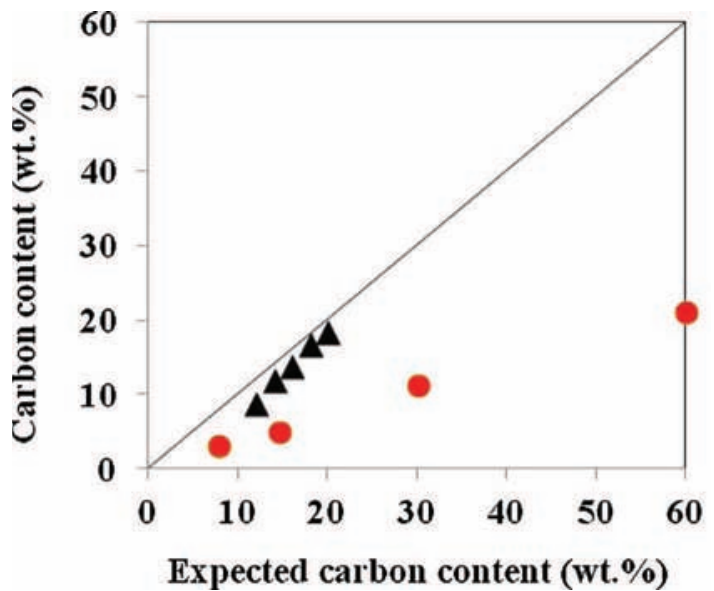

Fig. 2. Measured carbon content versus the expected carbon content for the $\mathrm{CNT} / \mathrm{Al}_{2} \mathrm{O}_{3}(\boldsymbol{\Delta})$ and graphite $/ \mathrm{Al}_{2} \mathrm{O}_{3}$ coatings $(\bullet)$. The solid line shows the expected carbon content (i.e. 1 for 1 )

( $5 \mathrm{~mol} \mathrm{~L}^{-1}$ ) under magnetic stirring at room temperature. The soobtained boehmite $(\mathrm{AlOOH})$ precipitate was filtered, washed with deionized water and oven-dried overnight, producing a boehmite 
powder. A known amount of this powder was dispersed into deionized water and the solution was peptized with a $3.1 \mathrm{vol} . \%$ solution of acetic acid (100\%) and stirred for $24 \mathrm{~h}$, producing a boehmite colloidal sol. Carbon was added in different proportions $(6,8,10,12$ and $14 \mathrm{~g} \mathrm{~L}^{-1}$ for CNTs and $5,10,25$ and $50 \mathrm{~g} \mathrm{~L}^{-1}$ for graphite), as required for the study. The carbon-boehmite sols were sonicated (Vibra Cell 75042 sonotrode), $1 \mathrm{~h}$ for CNTs and $0.5 \mathrm{~h}$ for graphite.

Stainless steel disks (AISI 304-L, diameter $30 \mathrm{~mm}$, thickness $5 \mathrm{~mm}$, arithmetic average roughness Ra $0.6 \mu \mathrm{m}$ ) were used as substrates. The disks were first pre-treated using a routine involving alkaline degreasing, acid pickling and nitric acid passivation [24].

\subsection{Preparation of the coatings}

$\mathrm{Al}_{2} \mathrm{O}_{3}$ and carbon- $\mathrm{Al}_{2} \mathrm{O}_{3}$ coatings were prepared by dip-coating followed by thermal treatments [24]. The stainless steel substrates were dipped into the boehmite or carbon-boehmite colloidal sols and withdrawn at a controlled speed $\left(300 \mathrm{~mm} \mathrm{~min}^{-1}\right)$, resulting in the deposition of a sol layer onto the substrate. After removing of the excess liquid, drying in air $\left(80^{\circ} \mathrm{C}, 2 \mathrm{~h}\right)$ provoked solvent evaporation and transformation of the sol in a xerogel. A heat-treatment in $\mathrm{N}_{2}\left(500^{\circ} \mathrm{C}, 25 \mathrm{~min}\right.$, heating rate $100^{\circ} \mathrm{Ch}^{-1}$, natural cooling) then resulted in the formation of the $\mathrm{Al}_{2} \mathrm{O}_{3}$ and carbon- $\mathrm{Al}_{2} \mathrm{O}_{3}$ coatings. The coatings will be referred to hereafter by a letter ( $\mathrm{T}$ for CNTs or $\mathrm{G}$ for graphite) and a number denoting its measured carbon content (weight\%), i.e. T18 or G21.

\subsection{Characterization}

The viscosity of the sols was measured using a viscometer (LAMY RM100) in a Taylor-Couette configuration at a shear range of $966-2900 \mathrm{~s}^{-1}$. Grazing incidence X-ray diffraction (XRD) was carried out on the substrate and on the coatings using a Siemens D5000 diffractometer with $\mathrm{Cu} \mathrm{K} \alpha \mathrm{X}$-ray source. XRD patterns were collected at room temperature by $0.02^{\circ}(2 \theta)$ scanning steps over the $10-100^{\circ}$ range. The carbon content in the carbon- $\mathrm{Al}_{2} \mathrm{O}_{3}$ coatings was obtained using an electron microprobe (EPMA, Cameca SXFive). The surface of the coatings was observed by field-emissiongun scanning electron microscopy (FESEM, JEOL JSM 6700F) and interferential rugosimetry (Zygo NewView 100). The thickness of the coatings was determined on cross-sectional SEM images (SEM JEOL 35CF). Cross sections were prepared by cryo-fracturation on notched samples. The wear tracks were observed by 3D optical profilometry (SENSOFAR S neox) and optical microscopy (Keyence VHX-1000E). Selected samples were studied by Raman spectroscopy (Horiba 800 spectrometer using $633 \mathrm{~nm}$ laser excitation). The spectra represent results obtained from three different areas in a given sample.
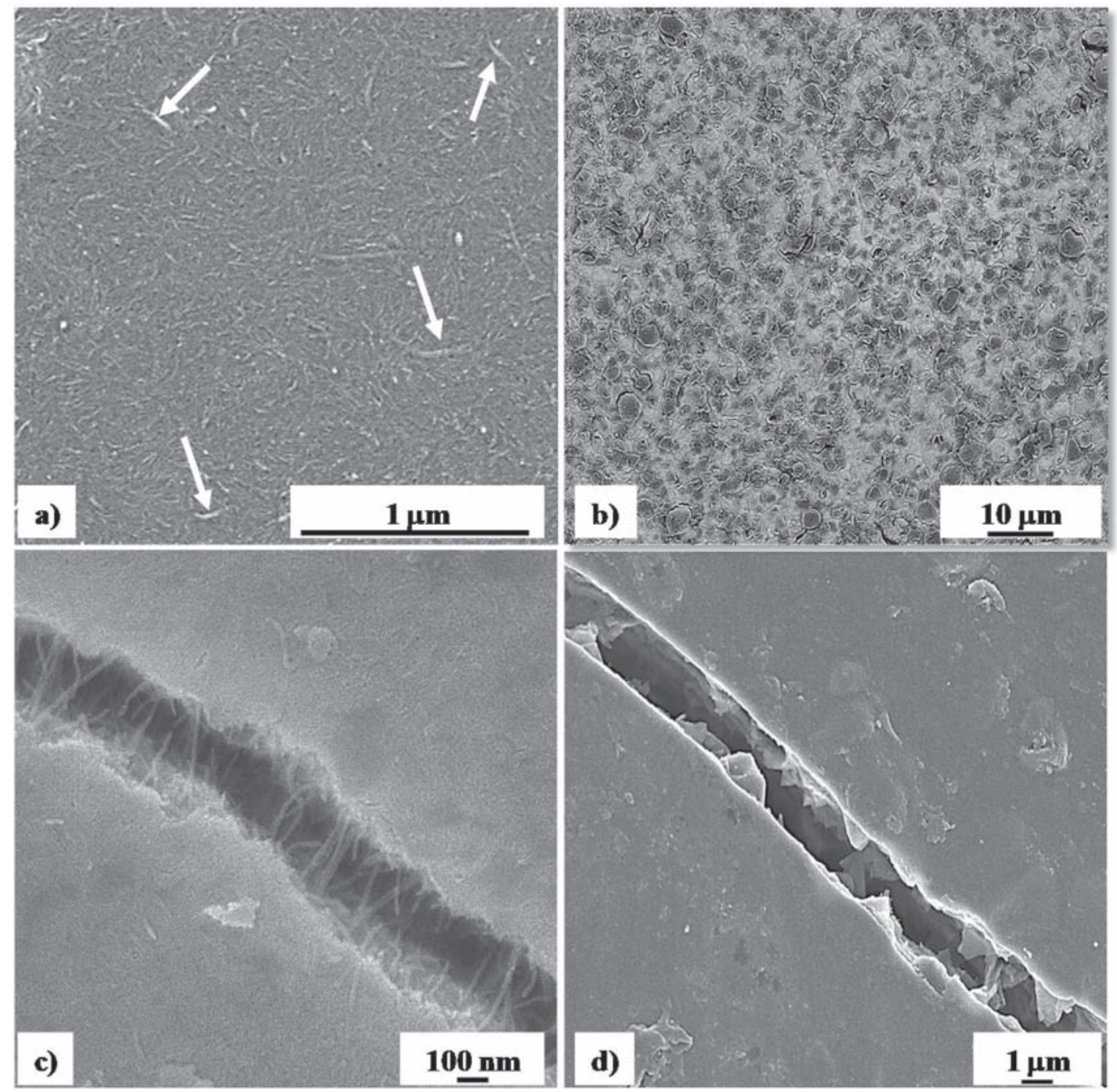

Fig. 3. FESEM images showing the surface of the $\mathrm{CNT} / \mathrm{Al}_{2} \mathrm{O}_{3}$ ( 18 wt.\%) (a) and graphite $/ \mathrm{Al}_{2} \mathrm{O}_{3}$ (21 wt.\%) (b) coatings and higher magnification images showing cracks made on purpose, with bridging CNTs for the CNT/ $/ \mathrm{Al}_{2} \mathrm{O}_{3}$ (18 wt.\%) coating (c) and non-bridging graphite platelets for the graphite/ $\mathrm{Al}_{2} \mathrm{O}_{3}(21 \mathrm{wt} . \%)$ coating (d). 

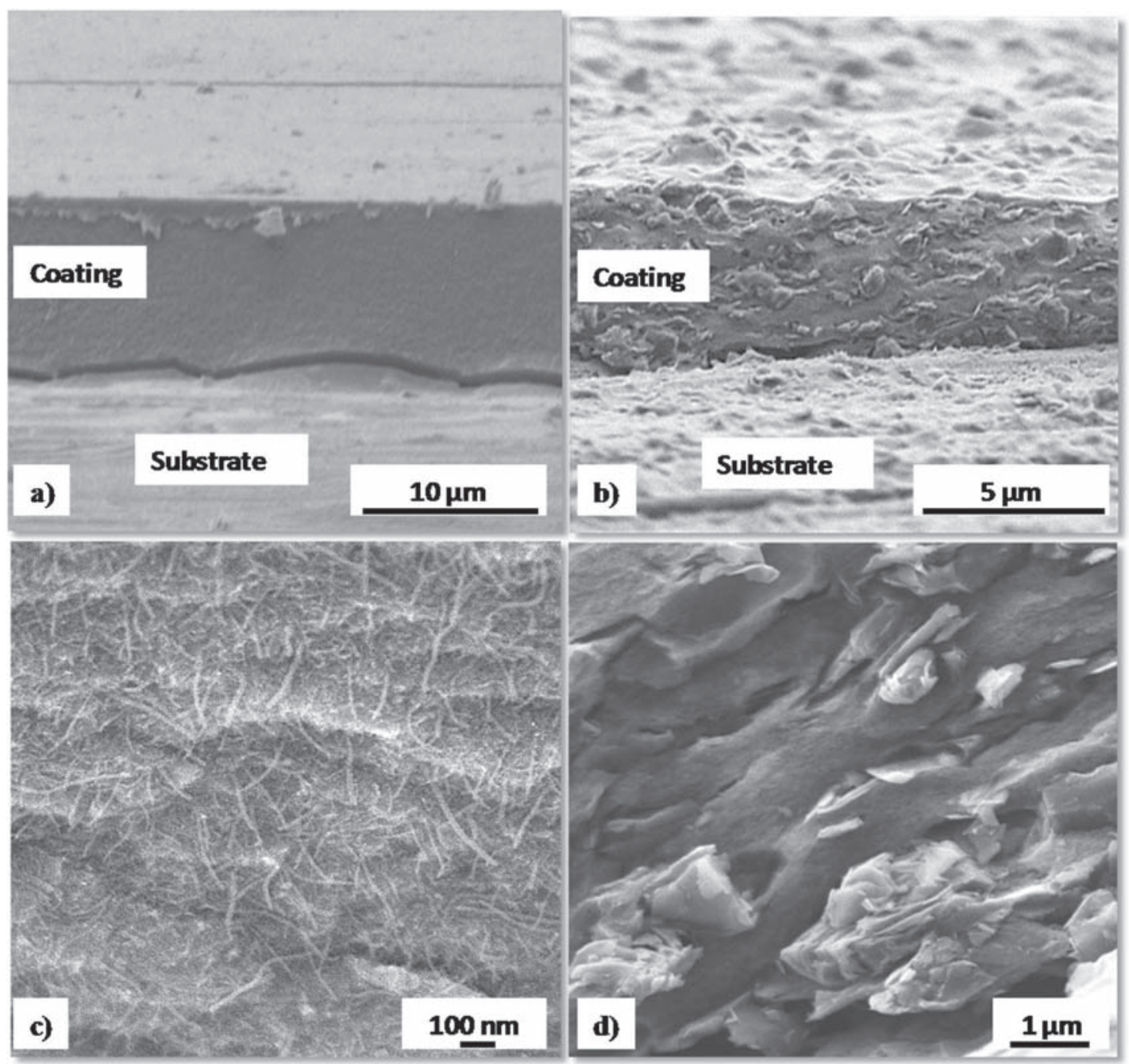

Fig. 4. FESEM images showing cross-sections of the $\mathrm{CNT} / \mathrm{Al}_{2} \mathrm{O}_{3}$ (18 wt.\%) coating (a) (white arrows indicate $\mathrm{CNTs}$ ) and graphite/Al $\mathrm{O}_{3}$ (21 wt.\%) (b) coating; higher magnification images show CNTs (c) and graphite platelets (d), respectively.

\subsection{Nano-indentation and tribological testing}

Instrumented indentation tests were conducted (in air at room temperature, maximum normal load $600 \mu \mathrm{N}$, load/unloading rate $800 \mu \mathrm{Nmin}^{-1}$, dwell $60 \mathrm{~s}$, maximum penetration depth 100-300 nm) with a Berkovich nano-indenter (CSM Instrument Ultra Nanoindenter) in order to record the load versus penetration depth and to evaluate the Young's modulus and hardness of the raw (i.e. un-polished) coatings. Friction tests were performed using a ball-on-disk geometry in rotary mode (CSM Tribometer) in compliance to the ASTM G99 international standard. Tests (normal load $2 \mathrm{~N}$, rotating speed $10 \mathrm{~cm} \mathrm{~s}^{-1}$ and total sliding distance $250 \mathrm{~m}$ ) were performed at room temperature in ambient air with a $40-60 \%$ relative humidity. The un-polished surfaces were rubbed against a 316-L steel ball $10 \mathrm{~mm}$ in diameter. The frictional force transferred to a load cell was recorded throughout the test. All friction tests were repeated three times, showing identical results.

\section{Results and discussion}

\subsection{Composition and microstructure of the coatings}

The viscosity of the sol increases markedly upon the increase in CNT content, from $11 \mathrm{mPa}$ s (pure boehmite sol) to $28 \mathrm{mPa}$ s for the sol with a carbon proportion of $14 \mathrm{~g} \mathrm{~L}^{-1}$. By contrast, the viscosity of the graphite-boehmite sols remains constant for all the studied carbon concentration range $\left(5-50 \mathrm{~g} \mathrm{~L}^{-1}\right)$ and is only marginally higher than for pure boehmite (13 vs $11 \mathrm{mPa}$ ). This could reflect the higher aspect ratio (length/diameter) of the 8CNTs (150) compared to that of graphite (1). The different carbon proportions $(6,8$, 10,12 and $14 \mathrm{~g} \mathrm{~L}^{-1}$ for 8 CNTs and 5, 10, 25 and $50 \mathrm{~g} \mathrm{~L}^{-1}$ for graphite) in the starting sols should yield carbon contents in the coatings equal to $12,14,16,18,20 \mathrm{wt}$.\% for 8CNTs and 7.9, 14.6, 30, $60 \mathrm{wt} . \%$ for graphite. The actual measured carbon content is $7-27 \%$ lower than expected for the $\mathrm{CNT} / \mathrm{Al}_{2} \mathrm{O}_{3}$ coatings (Fig. 2), but the discrepancy tends to diminish for higher contents, and is $62-68 \%$ lower than expected for the graphite $/ \mathrm{Al}_{2} \mathrm{O}_{3}$ coatings (Fig. 2), indicating that carbon species, in particular the graphite particles, tend to be drained by gravity during the withdrawing step of dip-coating if the viscosity of the sol is too low.

Analysis of the XRD pattern (not shown) for the un-coated 304-L steel substrate reveals the austenite (111) and (200) peaks (major phase) and a weak ferritic or martensitic peak (minor phase). For the $\mathrm{Al}_{2} \mathrm{O}_{3}$ coating, the steel peaks are less intense and no peaks corresponding to crystallized $\mathrm{Al}_{2} \mathrm{O}_{3}$ are detected. For the carbon$\mathrm{Al}_{2} \mathrm{O}_{3}$ coatings, very weak steel peaks are detected in addition to a strong CNT- or graphite (002) peak. Again, no peaks corresponding to $\mathrm{Al}_{2} \mathrm{O}_{3}$ are detected, showing that $\mathrm{Al}_{2} \mathrm{O}_{3}$ here is either amorphous or made up of extremely small crystallites. 

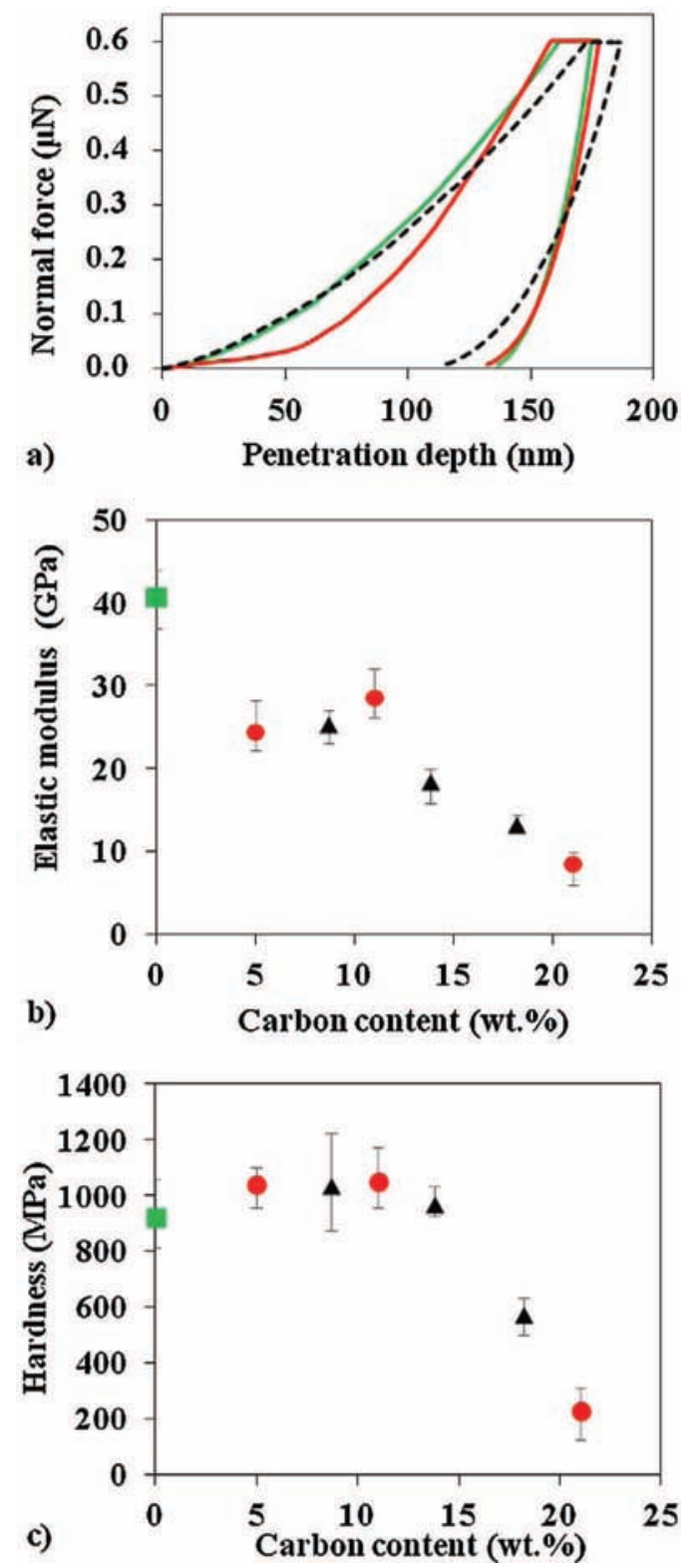

Fig. 5. Load versus displacement plots measured with a Berkovich nano-indenter (a), Young's modulus (b) and hardness (c) versus carbon content.

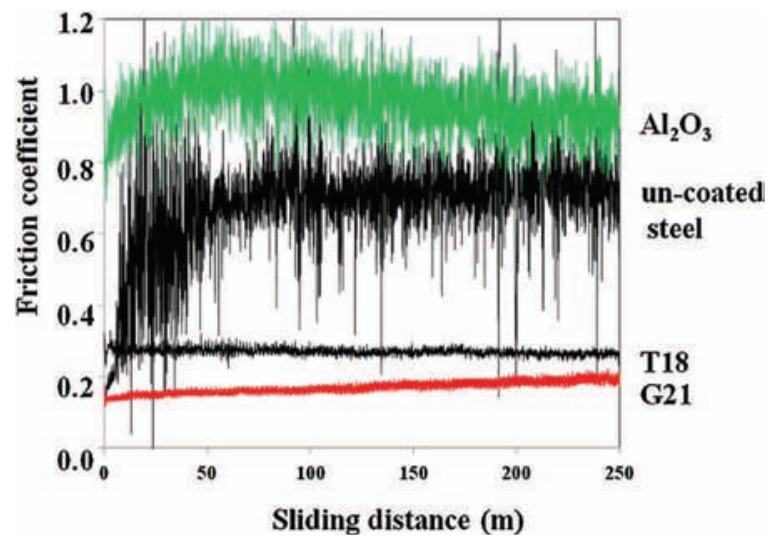

Fig. 6. Friction coefficient against a steel ball versus the sliding distance for the uncoated substrate and the $\mathrm{Al}_{2} \mathrm{O}_{3}, \mathrm{CNT} / \mathrm{Al}_{2} \mathrm{O}_{3}(18 \mathrm{wt} . \%)$ and graphite $/ \mathrm{Al}_{2} \mathrm{O}_{3}$ (21 wt.\%) coatings. The test load is equal to $2 \mathrm{~N}$.

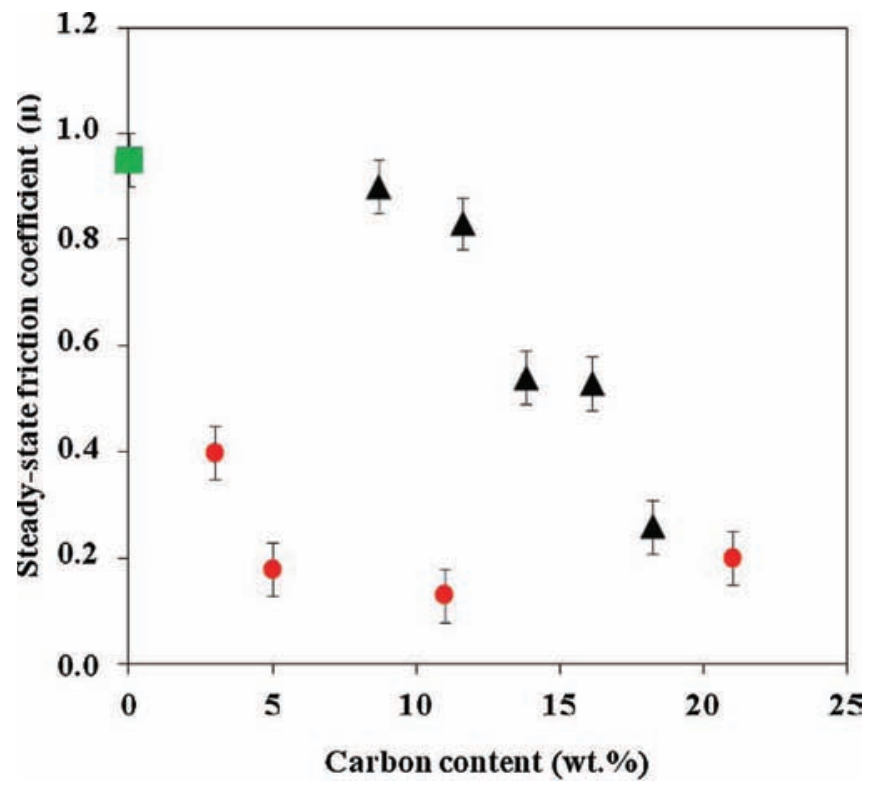

Fig. 7. Steady-state friction coefficient against a steel ball versus carbon content for the $\mathrm{Al}_{2} \mathrm{O}_{3}(\square), \mathrm{CNT} / \mathrm{Al}_{2} \mathrm{O}_{3}(\boldsymbol{\Delta})$ and graphite $/ \mathrm{Al}_{2} \mathrm{O}_{3}(\bullet)$ coatings.

FESEM observations of the surface of the coatings reveal a homogeneous distribution of the CNTs (Fig. 3a) and graphite platelets (Fig. 3b, back-scattered electron image in chemical composition mode). Cracks (Fig. $3 \mathrm{c}$ and d), were generated on purpose by performing high-load indentations. CNTs are observed bridging the crack (Fig. 3c), as could be expected from previous results [23,25], whereas the shorter platelets do not (Fig. 3d).

Cross-sections images such as those shown for T18 and G21 suggest that the T coatings (Fig. 4a) are less rough than the $\mathrm{G}$ coatings (Fig. 4b), as confirmed by white-light interferometry. Note that the crack between substrate and coating (Fig. 4a) was formed because the cross section was prepared by cryo-fracturation. The CNTs are homogenously dispersed within the coating (Fig. 4c). The graphite platelets mostly form micrometer-sized agglomerates (Fig. 4b) but individual platelets not thicker than $50 \mathrm{~nm}$ are observed in a highermagnification image (Fig. 4d). The thickness of the coatings was evaluated on similar images. It increases upon the increase in carbon content from $1 \mu \mathrm{m}$ for $\mathrm{Al}_{2} \mathrm{O}_{3}$ to about $7 \mu \mathrm{m}$ for $\mathrm{T} 18$ and about $5 \mu \mathrm{m}$ for G21.

Above a carbon content of $10 \mathrm{wt} . \%$, the higher thickness of the $\mathrm{T}$ coatings compared to that of the $\mathrm{G}$ coatings could be attributed to the higher viscosity of the corresponding sols. The arithmetic average roughness $\left(R_{a}\right)$ calculated from white-light interferential rugosimetry images (not shown) is equal to about $0.4 \mu \mathrm{m}$ for both the steel substrate and the $\mathrm{Al}_{2} \mathrm{O}_{3}$ coating, $0.8 \mu \mathrm{m}$ for the $\mathrm{G}$ coatings and only $0.2 \mu \mathrm{m}$ for the T coatings, in agreement with the FESEM observations where the T18 coating (Fig. 4a) seems to be more leveling towards the roughness of the steel substrate.

\subsection{Nano-indentation}

Typical load-penetration depth plots measured with a Berkovich nano-indenter are shown in Fig. 5a. The maximum penetration depth was kept lower than the tenth of the coating thickness for all samples, in order to neglect the influence of the substrate on the calculated mechanical properties. Analysis of such curves by the Oliver and Pharr method [26] shows that the Young's modulus of the coatings (Fig. $5 \mathrm{~b}$ ) steadily decreases upon the increase in carbon content, from $41 \mathrm{GPa}$ for $\mathrm{Al}_{2} \mathrm{O}_{3}$ to $9 \mathrm{GPa}$ for $\mathrm{G} 21$. The hardness (Fig. 5c) is constant (about $1000 \mathrm{MPa}$ ) from 0 to $14 \mathrm{wt}$.\% of carbon 

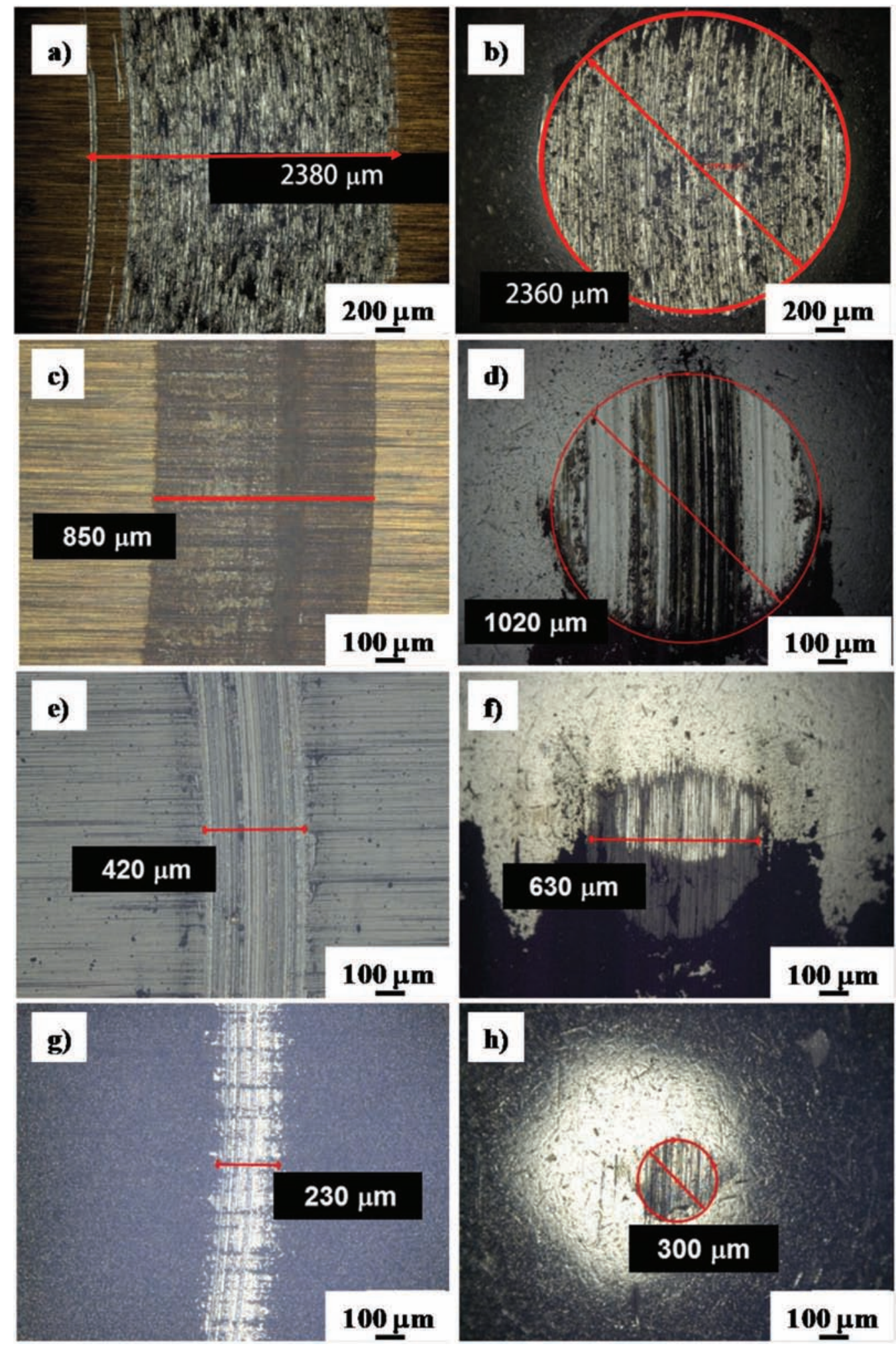

Fig. 8. Optical images showing the wear track for the un-coated substrate (a) and the $\mathrm{Al}_{2} \mathrm{O}_{3}(\mathrm{c}), \mathrm{CNT} \mathrm{Al}_{2} \mathrm{O}_{3}(18 \mathrm{wt}$. $)$ (e) and graphite/Al $\mathrm{O}_{3}(21$ wt.\%) (g) coatings and the corresponding steel balls (b, d, f and h, respectively).

and then decreases sharply, reaching only 200 MPa for G21. FESEM observation of the surfaces do not indicate a correspondingly lower densification, thus this could reflect a lower crystallization state of $\mathrm{Al}_{2} \mathrm{O}_{3}$, less cohesive grain boundaries or a weak carbon matrix interface.

\subsection{Tribological testing}

Typical curves showing the friction coefficient against a steel ball versus the sliding distance are shown in Fig. 6. The curves for the un-coated steel and $\mathrm{Al}_{2} \mathrm{O}_{3}$ coating are very unstable, which could reflect that wear is severe and a lot of debris is visibly generated 


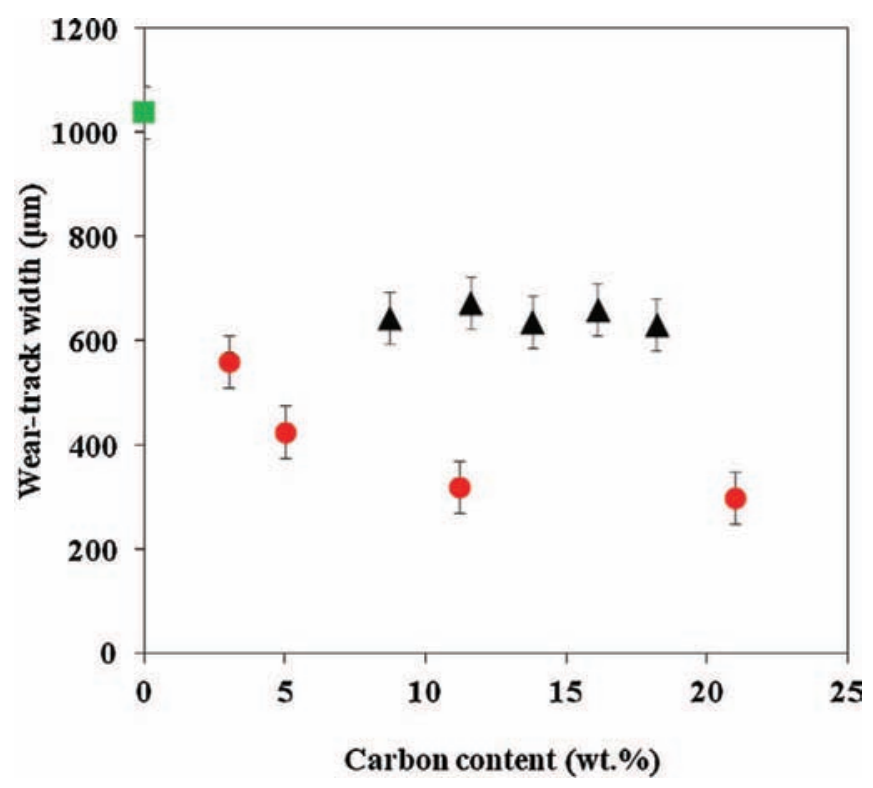

Fig. 9. Width of the wear tracks versus carbon content for the $\mathrm{Al}_{2} \mathrm{O}_{3}(\square), \mathrm{CNT} / \mathrm{Al}_{2} \mathrm{O}_{3}$ $(\mathbf{\Lambda})$ and graphite $/ \mathrm{Al}_{2} \mathrm{O}_{3}(\boldsymbol{Q})$ coatings.

(it was neither quantified nor imaged). For the T18 coating, there is a running-in period of about $20 \mathrm{~m}$, with a marked increase of the friction coefficient, and after which it is stabilized. This could reveal that the coating is separated from the substrate (reflecting total wear) very early in the test, possibly reflecting a weak coating/substrate interface. The so-produced debris would stay in the track and seemingly show a lubricating role that pure $\mathrm{Al}_{2} \mathrm{O}_{3}$ does not, which could be in agreement with reports by other authors $[18,19]$. For the G21 coating, there is a small but regular increase up to a sliding distance of about $200 \mathrm{~m}$.

Therefore, for all specimens, the average steady-state friction coefficient $(\mu)$ was calculated for the last $50 \mathrm{~m}$ of the tests. The $\mathrm{Al}_{2} \mathrm{O}_{3}$ coating $(\mu=0.95)$ does not provide any improvement on friction behavior over un-coated steel $(\mu=0.80)$. By contrast, $\mu$ decreases upon the increase in carbon content (Fig. 7), very progressively for the T coatings (reaching 0.26 for T18) and more abruptly for the $\mathrm{G}$ coatings for which a plateau at about $\mu=0.17$ is reached for G5.

Post-test optical observations of the wear tracks of selected coatings and the corresponding steel balls are presented in Fig. 8. The wear tracks of the composite coatings appear to be less wide and partially covered with a black film-like layer. This tribologically-formed film was transferred to the steel ball, suggesting that the observed lubricating effect during sliding may be at least partially related to the smearing of a tribofilm over the contact area. The width of the wear tracks (Fig. 9), measured on similar optical images, is lower for the composite coatings than for the $\mathrm{Al}_{2} \mathrm{O}_{3}$ coating $(>1000 \mu \mathrm{m})$. The value is constant (about $650 \mu \mathrm{m}$ for the $\mathrm{T}$ samples) and decreasing down to $300 \mu \mathrm{m}$ for the $\mathrm{G}$ specimens.

Wear tracks of selected samples (T18 and G21) were observed by non-contact optical profiler imaging (Fig. 10a and c) and the corresponding profiles perpendicular to the track (Fig. 10b and d) were used to measure their half-width and depth. Note that for T18 (Fig. 10b), the depth of the profile is close to the coating thickness (7 $\mu \mathrm{m}$, Fig. 7) which could confirm total wear as noted above. The wear volume $\left(\mathrm{V}_{\mathrm{w}}\right)$ was calculated for a half-ellipse track according to Eq. (1):

$\mathrm{V}_{\mathrm{W}}\left(\mathrm{mm}^{3}\right)=1 / 2 . \pi \mathrm{rd} .2 \pi \mathrm{L}$

with $\mathrm{r}=$ track half-width $(\mathrm{mm}), \mathrm{d}=$ track depth $(\mathrm{mm}), \mathrm{L}=$ outer radius of the circular track $(10 \mathrm{~mm})$.

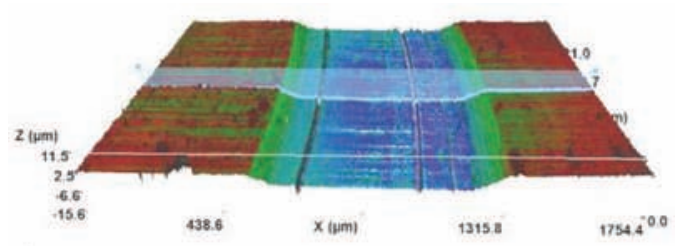

a)
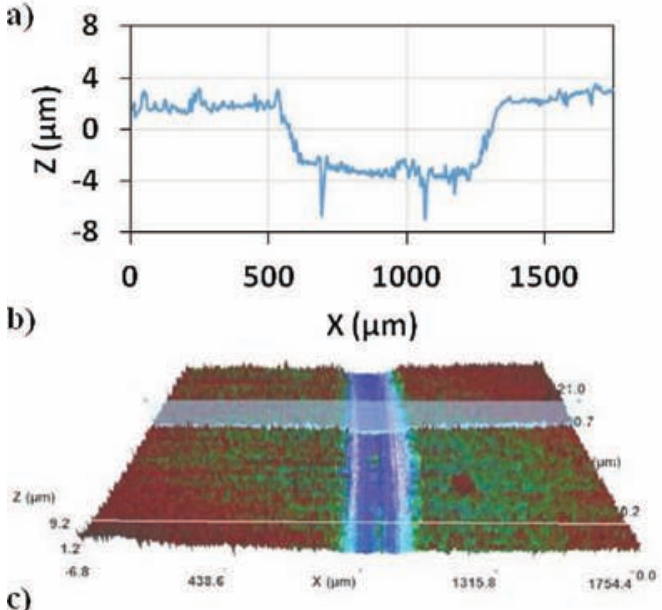

c)

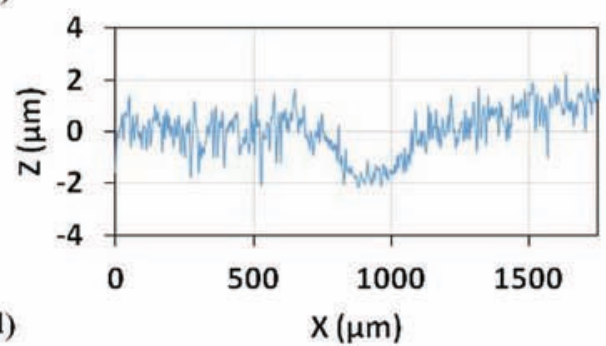

Fig. 10. White-light interferometry images of the wear tracks and the corresponding profiles for the $\mathrm{CNT} / \mathrm{Al}_{2} \mathrm{O}_{3}\left(18 \mathrm{wt} . \%\right.$ ) coating ( $\mathrm{a}$ and $\mathrm{b}$ ) and the graphite $/ \mathrm{Al}_{2} \mathrm{O}_{3}$ (21 wt.\%) coating (c and d).

The calculated wear volume for T18 and G21 is equal to 0.20 and $0.06 \mathrm{~mm}^{3}$, respectively. G21 is the most wear-resistant composite coating compared to un-coated steel $\left(0.30 \mathrm{~mm}^{3}\right)$ or $\mathrm{Al}_{2} \mathrm{O}_{3}$ coating $\left(0.12 \mathrm{~mm}^{3}\right)$.

\section{Discussion}

Although a detailed investigation of the wear mechanisms as performed by other authors $[18,19]$ is well beyond the scope of this work and warrants further studies, it was found of particular interest to study the wear tracks by Raman spectroscopy. Typical Raman spectra for T18 and G21, inside and outside the worn surface, are shown in Fig. 11. The ratio between the intensities of the D band and the $G$ band $\left(I_{D} / I_{G}\right)$ was calculated from the spectra. A higher ratio is generally attributed to the presence of more structural defects (more $\mathrm{sp}^{3}$ carbon). Interestingly, the spectra for T18 (Fig. 11a) are remarkably similar to each other and the $\mathrm{I}_{\mathrm{D}} / \mathrm{I}_{\mathrm{G}}$ ratio are similar too ( 1.83 outside and 1.90 inside). Moreover, it is also similar to the $I_{D} / I_{G}$ ratio (1.86 and 1.88) reported [23] for the raw and functionalized CNTs (same provider, same batch), respectively. These results indicate that the CNTs do not suffer drastic deterioration. It is probable that the more defective CNTs, those with a high number of walls, are destroyed because of the strong wear, very early in the friction test, resulting in the formation of a carbon/CNT/ $/ \mathrm{Al}_{2} \mathrm{O}_{3}$ tribofilm, the subsequent behavior of which does not favor CNT destruction and delamination. By contrast, the $\mathrm{I}_{\mathrm{D}} / \mathrm{I}_{\mathrm{G}}$ ratio for $\mathrm{G} 21$ (Fig. $11 \mathrm{~b}$ ) increases significantly from 0.42 (outside, and 0.40 for raw graphite) to 1.22 (inside), which could indicate some destruction of the graphite par- 

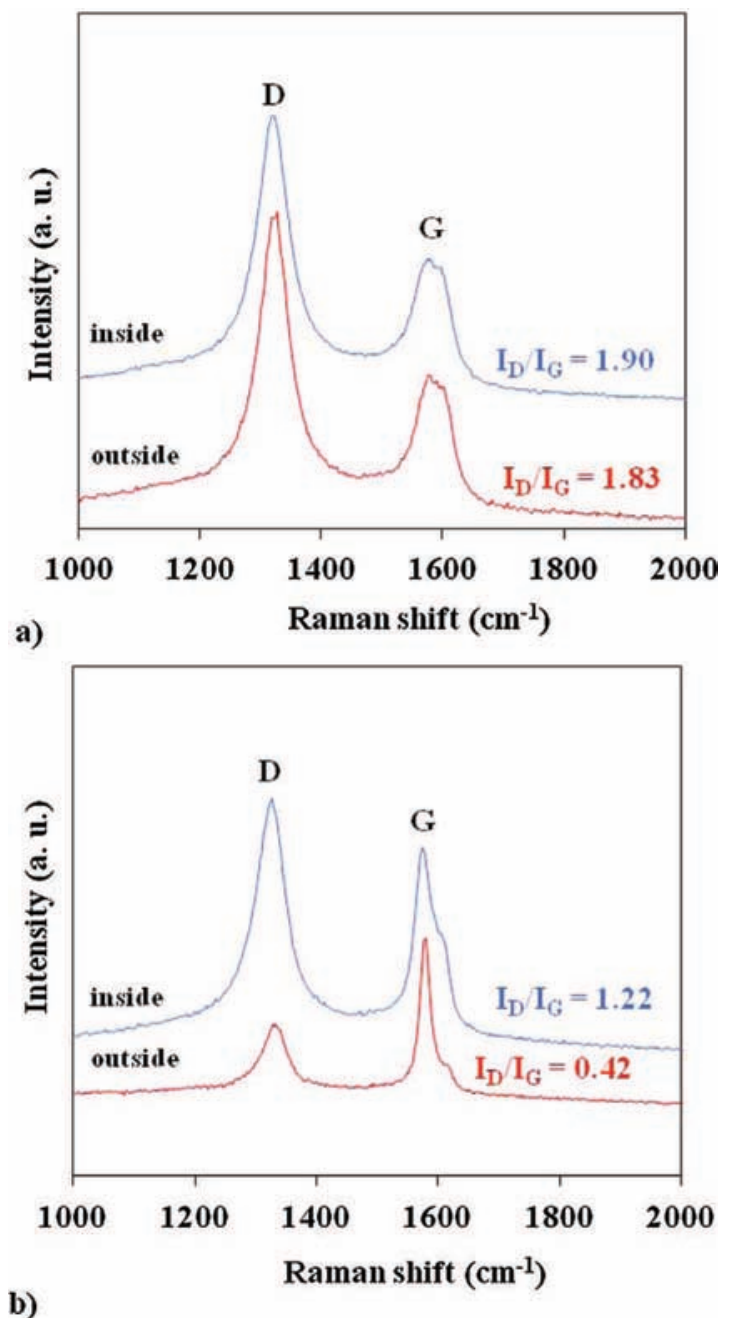

Fig. 11. Typical Raman spectra outside and inside the wear track for the $\mathrm{CNT} / \mathrm{Al}_{2} \mathrm{O}_{3}$ (18 wt.\%) (a) and graphite $/ \mathrm{Al}_{2} \mathrm{O}_{3}(21 \mathrm{wt} . \%$ ) (b) coatings.

ticles during the friction test. The so-generated debris would form a lubricating film, lowering the shearing resistance.

As mentioned above, the CNTs do not appear to be strongly damaged during the friction test and therefore the total carbon content in the samples is higher than the contributing, or "useful", carbon. The relative weight of each wall was calculated [27] and a plot (similar to the one in Fig. 7) of the steady-state friction coefficient versus the corrected carbon content was drawn (Fig. 12a), considering that the innermost wall is inactive (i.e. one counts only 7 walls), then that the two innermost walls are inactive (i.e. one counts only 6 walls), and so on until one counts only the outer wall, which contributes only $16.5 \%$ to the total weight of the CNT. The corresponding curves gradually shift to the left and interestingly the data when considering only the outer wall (labelled $1 \mathrm{~W}$ in Fig. 12a) fall reasonably in line with those of the graphite curve, forming what we consider to be a "master-curve". This suggests that instead of using weight or volumic carbon contents, the appropriate unit for tribological behavior could be the surface area developed by the involved carbon species. For the $\mathrm{CNT} / \mathrm{Al}_{2} \mathrm{O}_{3}$ specimens, the contributing surface area is thus estimated, admittedly roughly, as that calculated for the outer wall only, considering the geometric characteristics of the CNTs described in Section 2.1 and no bundling. Assuming that the contributing surface area is constant during the friction test, for a given sample, the corresponding plot of friction coefficient versus surface area forms the basis of

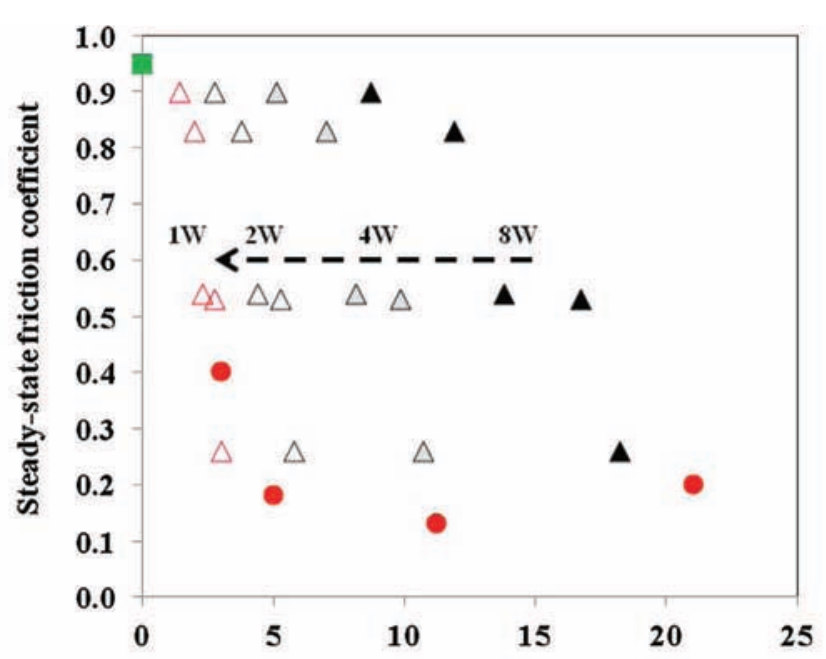

a)

Corrected carbon content (wt.\%)

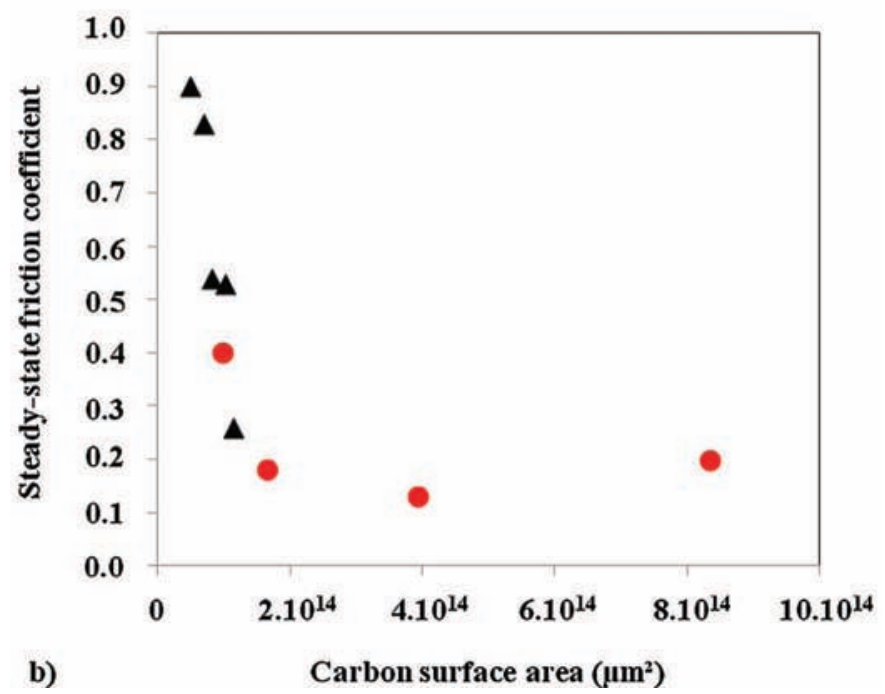

Fig. 12. (a) Steady-state friction coefficient versus corrected carbon content, considering only the number of walls considered active for the process (see text for details). Curves for 8, 4, 2 and 1 walls are shown. The arrow shows the gradual shift to the left; (b) steady-state friction coefficient versus the surface area of the carbon species involved in the friction phenomena (see text for details) for the CNT/ $\mathrm{Al}_{2} \mathrm{O}_{3}$ (triangles) and graphite $/ \mathrm{Al}_{2} \mathrm{O}_{3}(\bullet)$ coatings. The error bars have been omitted for clarity.

another "master-curve" (Fig. 12b). For the graphite $/ \mathrm{Al}_{2} \mathrm{O}_{3}$ specimens, the carbon flakes were first described as cylinders $1.5 \mu \mathrm{m}$ in diameter and $1.5 \mu \mathrm{m}$ thick (which obviously is far too thick) to get a the starting data for the calculation: the initial number of carbon flakes for a given weight content and the corresponding surface area (the vertical lateral area of the cylinder was neglected). Then, the cylinders were horizontally "sliced" in half, thus each time doubling the surface area developed by the carbon, until a reasonable fit with the "master-curve" (Fig. 12b) was obtained. This occurred after slicing 11 times and corresponds to a carbon layer about $730 \mathrm{pm}$ thick, i.e. close to two layers of graphene, which reasonably supports the finding that it is the graphene (graphite) surface available that is important for the reduction of friction and wear and that its initial form (either CNTs or graphite flakes) is un-important. Therefore, our results suggest that selecting graphite flakes is more convenient because, first it is easier to disperse into the boehmite sol and second it is more readily delaminated and broken into thinner flakes (also called few-layered-graphene) during the test, therefore providing more desirable lubricating surface area. 


\section{Conclusions}

Carbon $/ \mathrm{Al}_{2} \mathrm{O}_{3}$ coatings on 304-L stainless steel prepared using either CNTs (average number of walls $=8$ ) or graphite flakes present a lower friction coefficient (reduced by a factor of 4-5) and lower wear (reduced by a factor of 2 for graphite flakes) against steel compared to a pure $\mathrm{Al}_{2} \mathrm{O}_{3}$ coating. The CNTs and micrometersized graphite agglomerates are homogenously dispersed within the coatings, the thickness of which is in the 1-7 $\mu \mathrm{m}$ range. There is no dramatic deterioration of the structure of the CNTs during the friction test whereas the graphite flakes are partially destroyed. The $\mathrm{CNT} / \mathrm{Al}_{2} \mathrm{O}_{3}$ coating is separated from the substrate very early in the test, reflecting total wear, and the so-produced debris would show a lubricating role that pure $\mathrm{Al}_{2} \mathrm{O}_{3}$ does not, but however less efficiently than for graphite $/ \mathrm{Al}_{2} \mathrm{O}_{3}$ coatings. The so-generated debris form a lubricating film, which is transferred to the steel ball, suggesting that the observed lubricating effect during sliding may be at least partially related to the smearing of a transferred film over the contact area. Some simple modeling shows that only the outer wall of the CNTs contributes to the sliding, in agreement with the observed absence of major deterioration, and that the total available carbon surface area in the specimen is the relevant parameter. Therefore, it is shown that graphite flakes are more efficient than CNTs, at least in these experimental tribological conditions, because they are readily delaminated into thinner flakes (few-layered-graphene) during the test, providing more desirable lubricating surface area. These results provide important guidelines for the design of self-lubricating carbon $/ \mathrm{Al}_{2} \mathrm{O}_{3}$ coatings and future work directions include: the preparation of graphite $/ \mathrm{Al}_{2} \mathrm{O}_{3}$ coatings with thinner graphite flakes, and an in-depth study of the influence of the change in the coatings thickness, Young's modulus and hardness evolutions that were shown to occur upon the increase in carbon content.

\section{Acknowledgements}

This work was performed within the framework of CETIMAT, a joint laboratory between CETIM and CIRIMAT. K. Hentour and A. Marsal thank CETIM for the doctoral thesis grants. FESEM observations and electron microprobe analyses were performed at the Centre de microcaractérisation Raimond Castaing-UMS 3623, Toulouse. The authors also thank Dr. Ph. De Parseval for assistance in the electron microprobe analyses.

\section{References}

[1] J.P. Tu, Y.Z. Yang, L.Y. Wang, X.C. Ma, X.B. Zhang, Tribological properties of carbon nanotube-reinforced copper composites, Tribol. Lett. 10 (2001) 225-228, http://dx.doi.org/10.1023/A.1016662114589.

[2] S.R. Dong, J.P. Tu, X.B. Zhang, An investigation of the sliding wear behavior of Cu-matrix composite reinforced by carbon nanotubes, Mater. Sci. Eng. A 313 (2001) 83-87, http://dx.doi.org/10.1016/S0921-5093(01)00963-7.

[3] W.X. Chen, J.P. Tu, L.Y. Wang, H.Y. Gan, Z.D. Xu, X.B. Zhang, Tribological application of carbon nanotubes in a metal-based composite coating and composites, Carbon 41 (2003) 215-222, http://dx.doi.org/10.1016/S0008 6223(02)00265-8.

[4] B. Lim, C. Kim, B. Kim, U. Shim, S. Oh, B. Sung, J. Choi, Seunghyun Baik, The effects of interfacial bonding on mechanical properties of single-walled carbon nanotube reinforced copper matrix nanocomposites, Nanotechnology 17 (2006) 5759, http://dx.doi.org/10.1088/0957-4484/17/23/008.

[5] K.T. Kim, S.I. Cha, S.H. Hong, Hardness and wear resistance of carbon nanotube reinforced Cu matrix nanocomposites, Mater. Sci. Eng. A 449-451 (2007) 46-50, http://dx.doi.org/10.1016/j.msea.2006.02.310.

[6] S.R. Bakshi, D. Lahiri, A. Agarwal, Carbon nanotube reinforced metal matrix composites-a review, Int. Mater. Rev. 55 (2010) 41-64, http://dx.doi.org/10. 1179/095066009X12572530170543.
[7] C.B. Lin, Z.-C. Chang, Y.H. Tung, Y.-Y. Ko, Manufacturing and tribological properties of copper matrix/carbon nanotubes composites, Wear 270 (2011) 382-394, http://dx.doi.org/10.1016/j.wear.2010.11.010.

[8] K. Rajkumar, S. Aravindan, Tribological studies on microwave sintered copper-carbon nanotube composites, Wear 270 (2011) 613-621, http://dx. doi.org/10.1016/j.wear.2011.01.017.

[9] C. Guiderdoni, C. Estournès, A. Peigney, A. Weibel, V. Turq, C. Laurent, The preparation of double-walled carbon nanotube/Cu composites by spark plasma sintering, and their hardness and friction properties, Carbon 49 (2011) 4535-4543, http://dx.doi.org/10.1016/j.carbon.2011.06.063.

[10] C. Guiderdoni, E. Pavlenko, V. Turq, A. Weibel, P. Puech, C. Estournès, A. Peigney, W. Bacsa, C. Laurent, The preparation of carbon nanotube (CNT)/copper composites and the effect of the number of CNT walls on their hardness, friction and wear properties, Carbon 58 (2013) 185-197, http://dx. doi.org/10.1016/j.carbon.2013.02.049.

[11] Z. Xu, Q. Zhang, X. Shi, W. Zhai, Q. Zhu, Comparison of tribological properties of NiAl matrix composites containing graphite, carbon nanotubes, or graphene, J. Mater. Eng. Perform. 24 (2015) 1926-1936, http://dx.doi.org/10. 1007/s11665-015-1482-5.

[12] J.-W. An, D.-H. You, D.-S. Lim, Tribological properties of hot-pressed alumina-CNT composites, Wear 255 (2003) 677-681, http://dx.doi.org/10. 1016/s0043-1648(03)00216-3.

13] D.-S. Lim, D.-H. You, H.-J. Choi, S.-H. Lim, H. Jang, Effect of CNT distribution on tribological behavior of alumina-CNT composites, Wear 259 (2005) 539-544, http://dx.doi.org/10.1016/j.wear.2005.02.031.

[14] Z.H. Xia, J. Lou, W.A. Curtin, A multiscale experiment on the tribological behavior of aligned carbon nanotube/ceramic composites, Scr. Mater. 58 (2008) 223-226, http://dx.doi.org/10.1016/j.scriptamat.2007.09.039.

[15] G. Yamamoto, M. Omori, K. Yokomizo, T. Hashida, K. Adachi, Structural characterization and frictional properties of carbon nanotube/alumina composites prepared by precursor method, Mater. Sci. Eng. B 148 (2008) 265-269, http://dx.doi.org/10.1016/j.mseb.2007.09.013.

[16] I. Ahmad, A. Kennedy, Y.Q. Zhu, Wear resistant properties of multi-walled carbon nanotubes reinforced $\mathrm{Al}_{2} \mathrm{O}_{3}$ nanocomposites, Wear 269 (2010) 71-78, http://dx.doi.org/10.1016/j.wear.2010.03.009.

[17] A. Kasperski, A. Weibel, D. Alkattan, C. Estournès, V. Turq, C. Laurent, A. Peigney, Microhardness and friction coefficient of multi-walled carbon nanotube-yttria-stabilized $\mathrm{ZrO}_{2}$ composites prepared by spark plasma sintering, Scr. Mater. 69 (2013) 338-341, http://dx.doi.org/10.1016/j. scriptamat.2013.05.015

[18] K. Balani, S.P. Harimkar, A. Keshri, Y. Chen, N.B. Dahotre, A. Agarwal, Multiscale wear of plasma-sprayed carbon-nanotube-reinforced aluminum oxide nanocomposite coating, Acta Mater. 56 (2008) 5984-5994, http://dx. doi.org/10.1016/j.actamat.2008.08.020.

[19] A.K. Keshri, A. Agarwal, Wear behavior of plasma-sprayed carbon nanotube-reinforced aluminum oxide coating in marine and high-temperature environments, J. Therm. Spray Technol. 20 (2011) 1217-1230, http://dx.doi.org/10.1007/s11666-011-9669-2.

[20] C.-Y. Yu, B.J. Kellett, Tribology of alumina-graphite composites, in: J.B.W Jr. (Ed.), Proc. 20th Annu. Conf. Compos. Adv. Ceram. Mater. Struct. Ceram. Eng Sci. Proc., John Wiley \& Sons, Inc., 1996, pp. 220-227, http://dx.doi.org/10. 1002/9780470314821.ch26 http://onlinelibrary.wiley.com.

[21] J. Song, Y. Zhang, Y. Su, Y. Fang, L. Hu, Influence of structural parameters and compositions on the tribological properties of alumina/graphite laminated composites, Wear 338-339 (2015) 351-361, http://dx.doi.org/10.1016/j.wear. 2015.07.017.

[22] A. Peigney, C. Laurent, E. Flahaut, R.R. Bacsa, A. Rousset, Specific surface area of carbon nanotubes and bundles of carbon nanotubes, Carbon 39 (2001) 507-514, http://dx.doi.org/10.1016/S0008-6223(00)00155-X.

[23] A. Kasperski, A. Weibel, C. Estournès, C. Laurent, A. Peigney, Multi-walled carbon nanotube- $\mathrm{Al}_{2} \mathrm{O}_{3}$ composites: covalent or non-covalent functionalization for mechanical reinforcement, Scr. Mater. 75 (2014) 46-49, http://dx.doi.org/10.1016/j.scriptamat.2013.11.015.

[24] A. Marsal, F. Ansart, V. Turq, J.P. Bonino, J.M. Sobrino, Y.M. Chen, J. Garcia, Mechanical properties and tribological behavior of a silica or/and alumina coating prepared by sol-gel route on stainless steel, Surf. Coat. Technol. 237 (2013) 234-240, http://dx.doi.org/10.1016/j.surfcoat.2013.06.037.

[25] A. Peigney, F.L. Garcia, C. Estournès, A. Weibel, C. Laurent, Toughening and hardening in double-walled carbon nanotube/nanostructured magnesia composites, Carbon 48 (2010) 1952-1960, http://dx.doi.org/10.1016/j.carbon. 2010.01.063.

[26] W.C. Oliver, G.M. Pharr, Measurement of hardness and elastic modulus by instrumented indentation: advances in understanding and refinements to methodology, J. Mater. Res. 19 (2004) 3-20, http://dx.doi.org/10.1557/jmr. 2004.0002 .

[27] C. Laurent, E. Flahaut, A. Peigney, The weight and density of carbon nanotubes versus the number of walls and diameter, Carbon 48 (2010) 2994-2996, http://dx.doi.org/10.1016/j.carbon.2010.04.010. 